\title{
The Balanced Scorecard: Innovative Performance Measurement and Management Control System
}

\author{
Ondrej Zizlavsky'
}

\begin{abstract}
The paper presents an overview of studies that have described the emergence of innovative performance measurement systems. It is dedicated to the issue of potential implementation of Balanced Scorecard as a strategic management control system in Czech small and medium-sized enterprises. The framework is based on literature review and analysis about traditional management control systems, their pros and cons, and modern methods of performance measurement, such as Balanced Scorecard. Numerous publications discuss its potential advantages and recommend its implementation. On the other hand, there exist huge limitations for small and medium-sized enterprises, such as time, organization and money. Benefits resulting from successful Balanced Scorecard implementation must overweigh the costs of designing, implementing, and using it. Therefore, the paper is supposed to motivate researchers to conduct more large scale studies in the area of innovative performance measurement systems implementation in different business sector and areas.
\end{abstract}

Keywords: balanced scorecard; performance measurement; management control; innovation; innovation management; innovative potential; research and development; small and medium-sized enterprises; literature analysis; czech republic.

'Institute of Finances, Faculty of Business and Management Brno University of Technology, Kolejni 2906/4, 6I2 00 Brno, +420 54I I43 707, E-mail: zizlavsky@fbm.vutbr.cz

ISSN: 07 I8-2724. (http://www.jotmi.org)

Journal of Technology Management \& Innovation (c) Universidad Alberto Hurtado, Facultad de Economía y Negocios. 


\section{Introduction}

The old adage says: "You cannot manage what you don't measure." This is especially true for innovations where it is absolutely necessary to bring focus, intelligibility and discipline, particularly to the initial, inventive phase of the innovative process. Innovation is a continuous process. Companies continually create changes in their products and processes and gather new knowledge. Measuring such a dynamic process is much more complex than in a static activity.

Therefore, measuring performance and contribution to value of innovation has become a fundamental concern for managers and executives in the last decades (Kerssen-van Drongelen and Bilderbeek, 1999). According to the abundance of books and publications that have been written over the past few years on the topic of measuring company performance (see Neely (2005) for an overview about the state of the art of performance measurement and further research perspectives), it might seem that we know everything we need. In last years, many studies have been written aimed at discussing the issue and suggesting possible approaches to the performance measurement, innovation and R\&D management literature (e.g. Bassani et al., 2010; Chiessa and Frattini, 2009; Merschmann and Thonemann, 20I I).

Theoretical and empirical researchers analysed performance measurement systems about "continuous change", innovations (Boston Consulting Group, 2006) or relations between innovation and performance measurement systems implementation, with general and sector focuses (e.g. Fiorentino, 2010). Despite this, many companies do not have this issue supported and it is often taken for granted and considered resolved within the scope of the existing information systems.

Efficient and complex measurement systems are crucial to the success of innovations. It is not enough just to pick a few areas, use random indicators and expect to obtain the information needed for managing innovation. It ends up mostly in a situation where competent managers are overwhelmed with analysis results that they do not use in their work or that they use in a completely inefficient manner. This approach is time-consuming and draining on productivity. It can also lead to inconsistent analyses and incorrect measures (Davila et al., 2013).

\section{Methods}

The scientific aim of the paper is to gain knowledge and analyze the present status of innovative activities and their performance measurement as it pertains to the Czech and foreign professional literature. The objective of the article rests in the summary and presentation of results of a literature analysis of the relationship between innovative activities and performance measurement of a company. In addition, the paper is also important in terms of innovation management, which is a field of science, and also of related disciplines, specifically strategic management.

The paper is based on literature analysis of the Balanced Scorecard. The system approach, analysis, comparison and synthesis are applied in this paper.Analysis is used as a method of acquiring new knowledge and for its interpretation. When processing secondary data, the secondary analysis method was used. The professional literature, and particularly foreign resources, provided a source of secondary data. Comparison is used when various pros and cons of the Balanced Scorecard are compared. Synthesis is used for design of future research.

The first part reviews the literature and presents a brief history of management control systems development from traditional accounting control systems to the complex Balanced Scorecard performance measurement system. The next section is dedicated to the specification of the Balanced Scorecard model. The third section discusses benefits resulting from Balanced Scorecard implementation in the Czech business environment as well as barriers and potential problems incidental to its adoption. Finally, the last section summarizes the findings and gives a proposal for future research. From Traditional Accounting Control Systems to the Balanced Scorecard

Management control was defined by Anthony (1965) as "the process by which managers ensure that resources are obtained and used effectively and efficiently in the accomplishment of the organization's objectives." Management control systems have been commonly viewed as mechanisms designed to support the implementation of strategy at management level, while conceptually separating management control from strategic and operational controls. Within this framework, management control system research has focused mainly on accounting information produced primarily to measure cost efficiency and financial performance, while ignoring external aspects of the business (Aureli, 2010; Raake, 2008). 
In Czech economics most managers still use mainly financial indicators to assess business performance and its components. Some managers, due to their focus on economics only, have gone so far that they are trying to directly influence these indicators instead of trying to change the quality of their company's business, which in facts creates the indicator values. This approach is also enhanced by the current information systems used in companies that are full of economic information. It is because economic and financial values are easily measurable and most data can be taken from the company's accounting.

Other managers, focusing on matter-of-fact issues and knowing less about economics and finance, are usually overloaded by complex results of financial analyses supplied by the information system. In the end they usually do not employ the results of economic analyses in their work or use them in an inefficient way. An economic approach to measuring business performance is also preferred by the owners. Since they have invested their money in the company, they are expecting an appropriate return. From the owners' point of view a company is a "money-making-machine" and if it is not fulfilling this role the owners blame the management, and from their point of view they are right.

Financial indicators are indispensable for assessing business performance. Just they can inform the managers about the company's capability of creating value and allow them to check whether any employed measures contributed to the creation of value. Their main shortcoming is the fact that financial information reflects the results of managerial decisions made in the previous period and that their evolution is influenced by a number of factors that cannot be specified (Kislingerova, 2008). Complex financial indicators are also very hard to combine with the evolution of basic internal processes and further areas conditioning the success of the company. The rising criticism also covers aspects like missing alignment to corporate strategy, the backward view, the short-term perspective, insufficient customer orientation and misleading reference points for incentives (Gleich, 200I).

When business conditions in the 1980s changed - as globalization, the demand for customization, quality and speed revealed the above-mentioned limitations in traditional management accounting - it became evident that a review of this concept was necessary (Hayes and Abernathy, 1980; Johnson and Kaplan, 1987). The development and improvement of systems used to measure business performance therefore focused on adding non-financial indicators to accompany the financial ones - companies used them to measure and assess the development of basic success factors in individual strategic areas of their companies (Chakravarthy, 1986; Ittner and Larcker, 1998a; Kaplan and Norton, 1992; Merchant, 1985; Meyer, 1994; Nanni et al., 1992; Neuman et al., 2008; Palmer, 1992; Vaivio, 1999).
In this period leading global companies developed sophisticated indicator systems measuring performance, which proved to be ineffective in many cases - it was the result of an effort to create a perfect system and hence employing a large number of indicators. Gradually it became clear that those companies that picked a limited number of indicators actively selected by their management did achieve success in measuring business performance. Many new indicators were also introduced and tested, and assessment methodology was developed. The principle of balanced financial and nonfinancial criteria became well established.

Some of the most important management tools are for example the Performance Measurement Matrix (Keegan et al., 1989), the Performance Pyramid (McNair et al., 1990), the Integrated Performance Measurement Systems (Bitici et al., 1997), the Performance Prism (Neely and Adams, 200I), Data Envelope Analysis (Charnes et al., 1978), Quantum Performance Measurement (Hronec, 1993) or Productivity Measurement and Enhancement System (Pritchard, 2008). However, the most famous management model is the Balanced Scorecard proposed by Kaplan and Norton (1992, 1993, 1996, 200 la).

The success of the Balanced Scorecard is documented by its rapidly-growing worldwide popularity. In the more practitioner-oriented literature (e.g. Sibbet, 1997), the Balanced Scorecard concept has been celebrated as representing one of the most important management instruments in recent years. Surveys provide evidence for the rate of adoption of the Balanced Scorecard among the US firms up to $66 \%$ (Rigby, 2007). Since 1999 the Balanced Scorecard has been introduced in the Czech Republic.

A key factor of the fast spread of the Balanced Scorecard was the possibility of using a measuring system to control the implementation of company vision and strategy. Through this the Balanced Scorecard took up the role of a strategic management system (De Geuser et al., 2009).

The Balanced Scorecard approach inspired the European model of business success known as the EFQM Excellence Model (European Foundation for Quality Management, 1999), which is currently very popular in the EU. It is based on the initiative of 14 topWest European companies that established the European Foundation for Quality Management (EFQM) with the aim of improving the position of European companies in global competition (Westlund, 200I). EFQM Model Excellence is used to detect the problem points of a company and to warn about its weaknesses.

Similar to the Balanced Scorecard, although more than 50 years old, is the Tableau de Bord (Lebas, 1994) that has been used for decades by French managers to control perfor- 
mance on the basis of key control parameters regarding different organizational aspects of a company (Bessire and Baker, 2005; Bourguignon et al., 2004; Epstein and Manzoni, 1997).

\section{Balanced Scorecard}

Following section is dedicated to the specification of Balanced Scorecard model, the most famous and widely spread management control system.

\section{The Balanced Scorecard Model}

The better we understand innovation processes the better our business model will be as well as the related system of measuring performance, which will supply better information for innovation management. This is why it seems best to use Balanced Scorecard (BSC) process classification, which is based on the value chain and covers all the key company processes:

- Innovation process - company is studying the development of customers' needs and based upon the results it organizes research and development of new products that satisfy these needs.

- Operational process - ensure production and supply of products and services to customers.

- $\quad$ Post-sale services - can represent an advantage in business competition. It can be e.g. fast service of sophisticated and expensive systems or training programs supporting efficient use of these products.
The advantage of this method is that the transition from strategic to process level achieved through process perspective is very straightforward. Another advantage of this value chain is that the innovation process stands at its beginning and that it includes the investigation of current and future needs of the customers, as well as research and development of new ways how these needs could be satisfied.

The above-described value-creating process is established to fulfil the company's mission and it directly produces the added value satisfying the needs of the customer. It is easiest to track it from its end - from the added value for both customer and owner, which must be balanced in the longterm. It can be extended by auxiliary and supportive processes. Key processes in the innovation process model must include identification of new product concepts, development of product from new concepts, process innovation in production, acquisition of technologies (development and control of technologies). Supportive processes are represented by resources and their distribution, efficient use of relevant systems and tools ensuring leadership or management.

The BSC concept transforms company vision and strategy into a comprehensive set of performance indicators that provides a framework for assessing its strategy and management system. BSC measures company performance using four balanced perspectives - financial, customer, internal business processes and potential (Kaplan and Norton, 1992; Horvath and Partners, 2002). It allows for monitoring financial results as well as the ability of the company to source

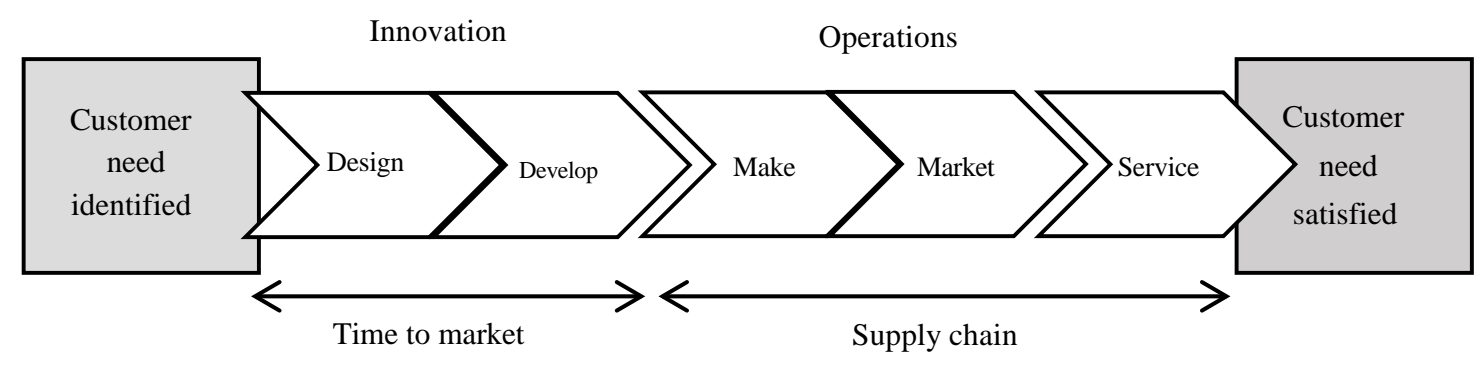

Business processes

Innovation process

- $\quad$ Product design

- $\quad$ Product development
Operations process

- $\quad$ Manufacturing

- $\quad$ Marketing

- $\quad$ Post sale service

Figure I.The internal business process value chain perspective. Based on Kaplan and Norton (1996)

ISSN: 07 I 8-2724. (http://www.jotmi.org) 
assets needed for its growth and increasing competitiveness, ability to create value for current and future customers, and capacity of improving the quality of human resources, systems and methods of work necessary for increasing their future performance.

Balance is the equilibrium between operative and strategic (short-term and long-term) goals, required inputs and outputs, internal and external performance factors, delayed and driving indicators, and also the already mentioned financial and non-financial indicators. These perspectives are not selected without any purpose - they allow for a comprehensible view of combining the company's success with the drivers of performance. BSC thus represents a flexible system within a strategy.

BSC is one of the most popular and practical concepts of systems used for measuring business performance. Although its original idea focused on business strategy it can be applied to any process in a company, including innovation (e.g. Bremser and Barsky, 2004; Kerrsens-van Drongelen et al., 2000; Neufeld et al., 200 I). Innovative companies use it as strategic management system, i.e. to manage their long-term strategy and to perform critical management processes.
There are five basic principles for a strategy-focused organization using the BSC, which can be summarized as follows (Kaplan and Norton, 200 lb):

- $\quad$ Translate the strategy into operational terms using balanced scorecards and strategy maps;

- $\quad$ Align the organization to the strategy by cascading the highest-level scorecard to strategic business units, support departments, and external partners;

- Make strategy everyone's job with initiatives to create strategic awareness and by using personal scorecards with related incentives;

- $\quad$ Make strategy a continual process by linking budgets to strategy, implementing a process for learning and adapting firm strategy; and

- Mobilize leadership for change to a strategic management system.

The key features in this system are the result indicators, which are general and are applicable in different types of company. They are also known as delayed indicators, because they are used to measure past results. Such indicators are e.g. profitability indicators, sales revenue, customer satisfaction, market share, etc. The second type of indicator used in

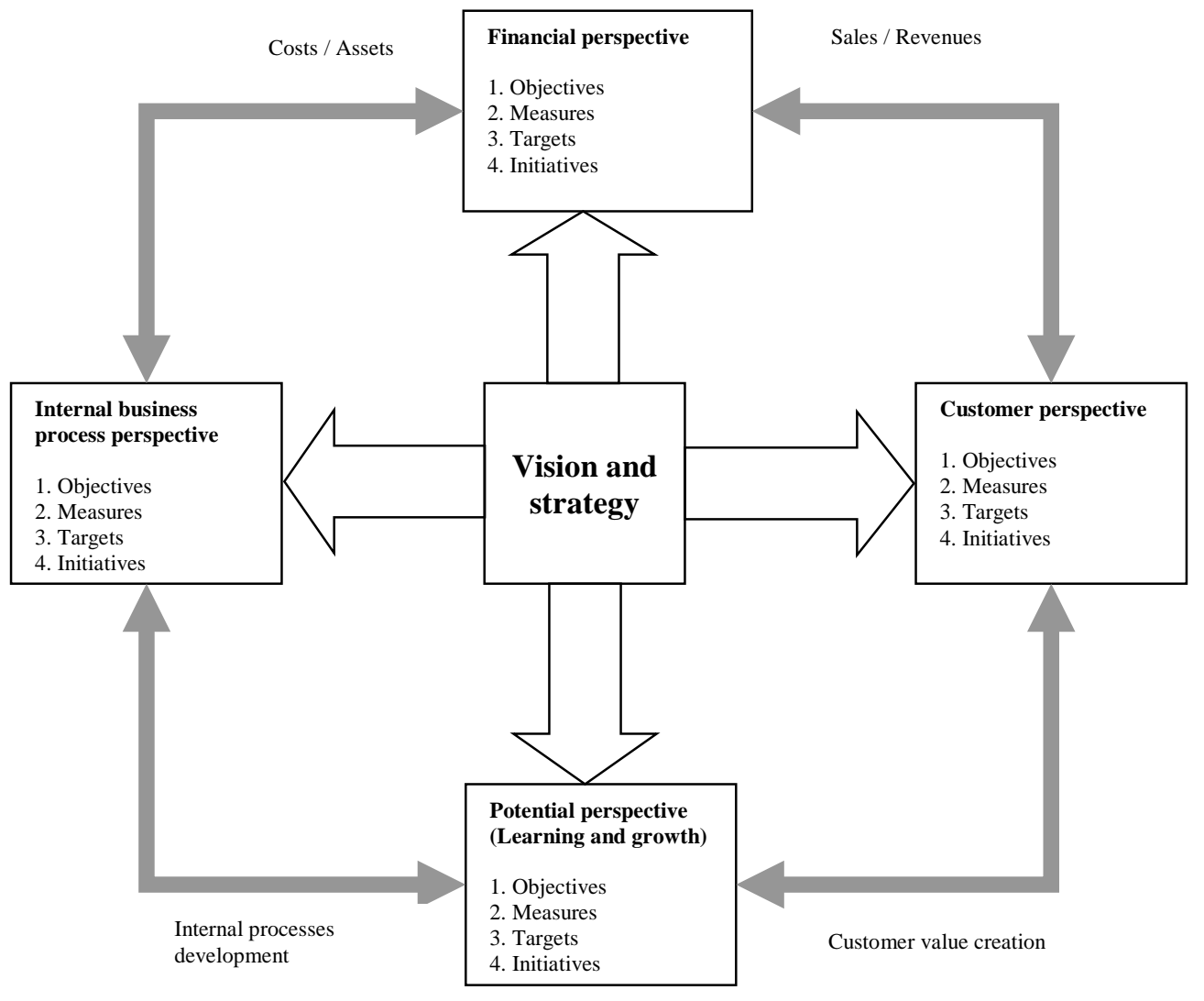

Figure 2.The Balanced Scorecard framework. Based on Kaplan and Norton (1996) and Horvath and Partnes (2002)

ISSN: 07 I8-2724. (http://www.jotmi.org)

Journal of Technology Management \& Innovation (c) Universidad Alberto Hurtado, Facultad de Economía y Negocios. 
BSC are the driving indicators, which usually differ for each company. They are sometimes known as advance indicators, because their current development advances future results. These may include e.g. turnover increase, productiveness increase, and value increase for the customer, staff requalification, etc. The moving powers of long-term financial success may ask for brand new products to satisfy the needs of current and future customers. The innovation process is understood as the long-term creation of values and for many companies the future financial performance is a stronger moving power than the short-term cycle of operation. From the perspective of future economic performance it is much more important for many businesses to be able to successfully manage a long process of developing a brand new product or develop the company's ability to address a new group of customers than consistent management of current operations (Kaplan and Norton, 1996; Niven, 2005).

The BSC is a management system designed to link and align the company with its strategy at all levels. After the balanced scorecard is formulated at the corporate level of the company, it is cascaded downward to strategic business units and support departments (Niven, 2006). These units develop scorecards to implement the strategy communicated by the corporate scorecard. Full implementation of the BSC model requires cascading down to the individual level. This provides for each person having a perspective on his or her role in strategy implementation. For each measure in the personal scorecard, strategy implementation goals are set. Incentives such as stock options and merit pay increases are linked to their performance in implementing strategy. Measurements are used throughout the organization to implement strategy and achieve synergies. Cascading corporate BSC to the innovative function and the R\&D department aims to achieve integration of technology planning with business strategy (Bremser and Barsky, 2004; Kaplan and Norton, 200 l b).

\section{The Balanced Scorecard Model \& Innovation}

BSC understands innovation as a critical internal process. The higher priority of the innovation cycle over the operating cycle is specifically notable in companies with a long term of development and design. Once the product reaches the production phase here, the margins from operation may be quite high. Opportunities for further cost reduction may also be limited. Most costs occur during research and development. Some estimates claim $70-80 \%$ (e.g. Serfling and Schultze, 1997).
During the process of innovation a company uses strategic marketing to investigate the development of customers' needs and based on the results of such investigation it organizes its research and development into new products to satisfy these needs. On the other hand, the operating process represents a short wave of creating value in which companies supply existing products to existing customers.

The BSC Innovation process consists of two features (see Figure I in Innovation section). First of all managers use the results of market research to learn about its size, character, customer preferences and bases for setting prices of the target products. Once the companies develop their internal processes towards satisfying concrete customer needs, availability of the right information about market size and customer preferences is the main road to success. Besides investigating the needs of existing and potential customers this segment may provide information about totally new opportunities and markets for products that could be supplied by the company. Information about markets and customers serve as input for the second step in the innovation process, i.e. the process of new product development (Kaplan and Norton, 1996). The key tasks of the development team are:

- Through basic research to look for sources of value for brand new products.

- Within applied research and development to project the results of basic research into the design of new generations of product.

- To strive for introduction of new products to serial production and on the market.

Development of performance criteria and product development received relatively low attention in the past. This was because most attention in companies focused on production and operation processes, not on research and development. Production processes consumed much more money than research and development. Many companies nowadays need to gain a competitive advantage by constantly launching new innovated products, which makes the research and development process an important component of their value chain. The success of this process should be verified using concrete goals and criteria.

The relation between inputs consumed during development (salaries, equipment, material) and achieved outputs (innovated products) is much more misleading than in the process of production where it is relatively easy to quantify labour, material and equipment needed to make the product. Applicability of different performance standards and criteria also strongly depends on the length of the development cycle. 
Criteria for basic and applied research are determined upon the companies' perspective by the importance assigned to the individual aspects of the innovation cycle. Their dimension can be either marketing:

- $\quad$ percentage of new product sales from sales total,

- $\quad$ percentage of sales of products protected by law from sales total,

- launching of a new product on the market compared with competitors,

- launching of a new product compared with plan,

- length of time needed for developing a new generation of products,

or financial and analytical:

- profitability of R\&D costs,

- degree of operational cost before tax per concrete period compared to total cost of development.
Table I presents an example of specific metrics for innovation in the BSC framework. The four perspectives of the BSC provide a context for the measures. The literature cited above suggests many possible measures. The BSC implementation process includes careful selection of measures to implement strategy. Measures will change over time due to the strategic learning loop. If companies want to achieve their stated innovative vision, it is important that employees see how their responsibilities contribute to strategic success. An example shows strategic indicators at the company level and measurements at the R\&D Department level from the cascading down process.

Bremser and Barsky (2004) recommend a participative cascading approach, which calls for consensus agreement between managers at upper and lower levels. The process starts with a statement of strategic indicators at the firm level. These measurements and supporting documentation on how they relate to strategy implementation are communicated downward to strategic business units, divisions or departments, depending on the organizational structure. If the next level is the division in the organizational structure, the division would prepare a balanced scorecard and cascade it down to the departments below. The various departments at the next level would review possible metrics for their balanced scorecard that linked to the cascaded down measures.

\begin{tabular}{|l|l|l|}
\hline Strategic objectives & Strategic indicators at company level & Sample metrics at R\&D department level \\
\hline Financial perspective & $\begin{array}{l}\text { Return on capital employed } \\
\text { Customer profitability } \\
\text { Revenue growth rate }\end{array}$ & $\begin{array}{l}\text { R\&D value creation at innovation stages } \\
\text { R\&D value creation at commercialization stages }\end{array}$ \\
\hline Customer perspective & $\begin{array}{l}\text { Customer retention rate } \\
\text { Market share } \\
\text { Customer acquisition (number and } \\
\text { quality) }\end{array}$ & $\begin{array}{l}\text { Percentage of sales from new products } \\
\text { Product market life cycle } \\
\text { Customer satisfaction with new products }\end{array}$ \\
\hline $\begin{array}{l}\text { Internal business process perspec- } \\
\text { tive }\end{array}$ & $\begin{array}{l}\text { New product profitability } \\
\text { R\&D efficiency (time to market) } \\
\text { Percentage of resources to sustain } \\
\text { existing products } \\
\text { Other metrics not related to R\&D }\end{array}$ & $\begin{array}{l}\text { Number of new products approved for market launch } \\
\text { Average development cycle time } \\
\text { Percentage of ideas approved for test and validation } \\
\text { phase } \\
\text { Pricing and profit planning accuracy } \\
\text { New product acceptance rate } \\
\text { Safety incidents }\end{array}$ \\
\hline $\begin{array}{l}\text { Potential perspective (Learning and } \\
\text { growth) }\end{array}$ & $\begin{array}{l}\text { Employee retention } \\
\text { Employee development } \\
\text { Strategic skill coverage ratio by } \\
\text { competency category } \\
\text { Employee survey measures } \\
\text { Innovative culture surveys }\end{array}$ & $\begin{array}{l}\text { Number of patents awarded } \\
\text { Strategic skill coverage ratio by competency category } \\
\text { R\&D competency vs. competitors (innovation level) } \\
\text { Employee survey measures } \\
\text { Employee training (hours) }\end{array}$ \\
\hline
\end{tabular}

Table I.Application of the BSC to R\&D. Based on Bremser and Barsky (2004, p. 235)

ISSN: 07 I8-2724. (http://www.jotmi.org) 
The BSC Model \& Innovative Potential Development

The BSC methodology can be used also to characterize the company development potential, because its interpretation of the company's value is based on the mutual interaction of four perspectives of change:

- change in workers' behavior,

- change of internal environment in the company,

- change of consumer behavior of the customers,

- change of company's economy.

According to Figure 3, published by Pitra (2006), business development is initiated by increasing work performance of company workers (caused by their higher satisfaction with their own work, higher level of their expert skill and more efficient motivation), which is reflected in increasing productivity and innovation development in the company's internal environment. The result of this development is an offer of products that bring higher value to the customers. Increased demand for quality, user-friendly, easily accessible and reasonably priced products offered by the company leads to increased sales revenues. Higher revenues increase profit and therefore also the earning power and value of the company.At the same time they create resources to finance investment and operating capital for efficient financial management of the company.

\section{Discussion}

The effects and potential of implementing BSC may be great and very tempting (e.g. Horvath and Partnes, 2002; Kaplan and Norton, 1996):

- The BSC indicator system will enable continuous control over the meeting of strategic goals through fulfilling performance indicators. This creates strong feedback allowing for fast updating of an unrealistic strategy. BSC will provide an overview of the actual performance of all internal company processes, which enables efficient management of process performance enhancing, including the evaluation of actually achieved efficiency of investments. BSC provides an overview of the causal structure of the company, the main factors of performance, their development and mutual relations.

- BSC will allow for efficient communication between all organisational units of the company during the implementation of a strategy, and implement feedback for adjustment of goals set for organisational units and individuals with the goals of the company.

- BSC concentrates attention of the management and all other workers on fulfilling the strategy, therefore on creating future prospects. The checking of past development is just a tool.

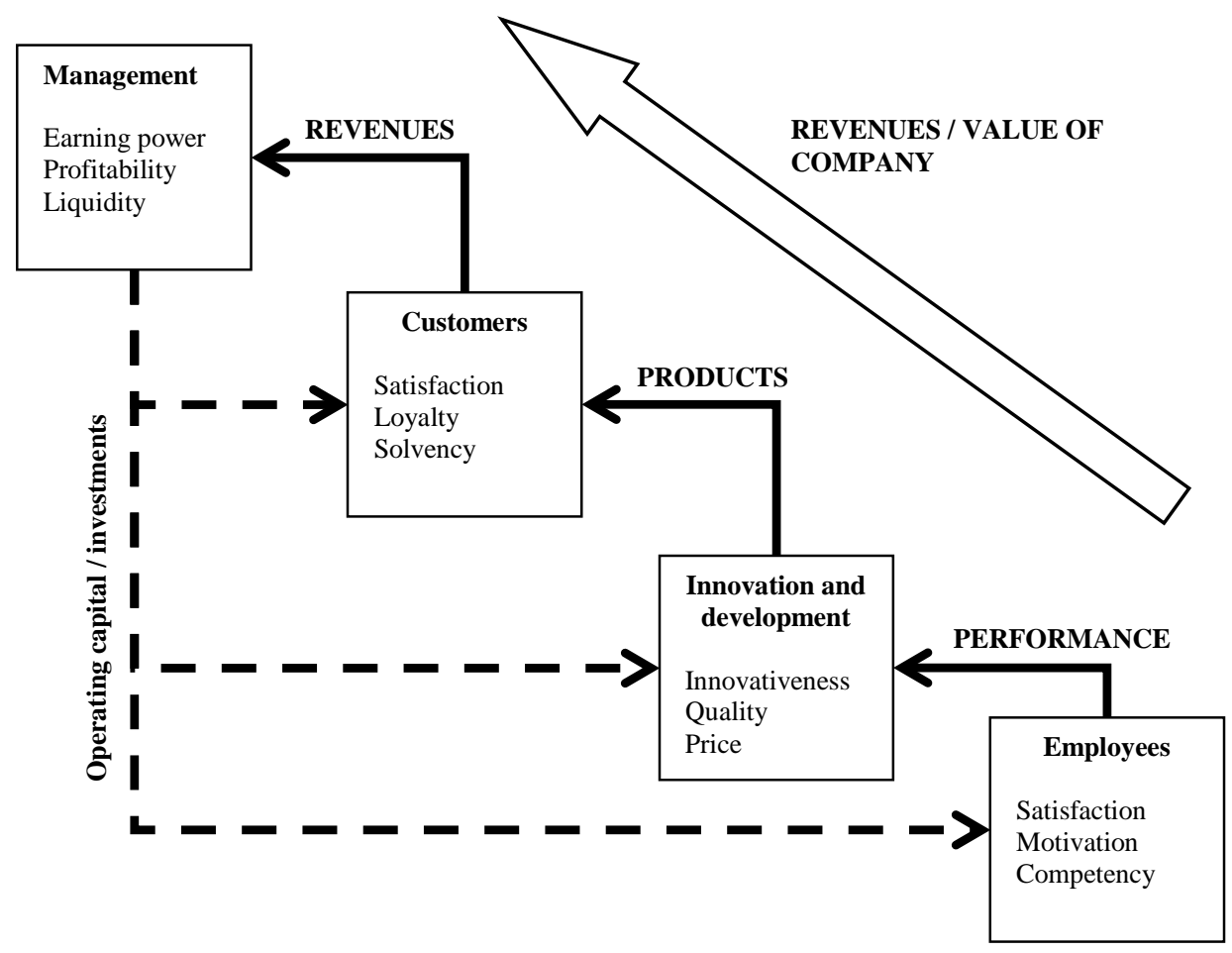

Figure 3. Company development through BSC. Based on Pitra (2006)

ISSN: 07 I8-2724. (http://www.jotmi.org) 
A well-implemented BSC system allows for efficient following of a company innovation strategy. However, its implementation must be done properly with regard to company's aims, strategy, advanced management system, information support and communication.

A formal model of BSC implementation was presented by the Hungarian scientist Peter Horvath (Horvath and Partners, 2004; Horvath and Partners, 2002). His experience shows that in the preparation of a project the first step in BSC implementation must be assessment of the company's preparedness for the project implementation. Moreover, successful BSC implementation, especially in small and medium enterprises, is possible only in collaboration with a specialised consulting company. An unbiased view from the outside is needed mainly for the setting-up of the entire BSC programme and first steps of implementation. For the final success of a BSC project it is necessary that during implementation the initiative must be gradually accepted by all the internal team members, who will identify with the results and adopt them.

During preliminary research in 20I0-20II the word "scorecard" was mentioned to several managers who immediately recalled the Balanced Scorecard system. However, there are still just a few companies using the BSC system in the Czech environment. The questioned companies did not use this system, but had established different systems of measuring performance. This misbalance reflects the reality of historic concentration on savings. Unfortunately, introduction of an integrated BSC system, although its philosophy is simple and logical, is very difficult for small and medium Czech companies in terms of time, organisation and money. In the current situation Czech companies must also deal with problems in company culture and motivation of workers towards an active approach to increasing innovation performance. Based upon contacts with managers and owners of Czech corporations it can be said that although they are interested in modern management methods, there are many barriers preventing the implementation of BSC:

- Companies do not constantly perform benchmarking and a deeper knowledge of competitors and the market is missing. Marketing information systems are not consistently created and filled (Zizlavsky and Smakalova, 20I I).

- $\quad$ Strategic company management is formal and has a campaign character. Visions are very vague and strategic goals are formulated generally and in terms of quality only. Due to poor knowledge of competitors the strategic goals do not focus on key factors of success.

- Due to generally formulated targets, investments necessary for implementing strategies are spent upon the management's consideration and without relation to the strategy.
- Strategy is not communicated within the entire company and workers lack motivation for fulfilling it.

- The long-neglected issue of human resources is becoming a critical factor of further development. The condition of further efficient company development is to achieve agreement on distribution of created value between customers, owners, employees and suppliers (Horvath and Partners, 2002; Kaplan and Norton, 1996).

The inventors of this method are aware of the mentioned limitations. They point out that it is a dynamic system, which must flexibly react to the changing character of the business environment (Kaplan and Norton, $200 \mathrm{la}, \mathrm{b}$ ). BSC is thus forced to undergo evolution (Cobbold and Lawrie, 2002; Horvath and Partners, 2002). Being aware of these limitations many authors have contributed to the development of the BSC model (e.g. Hoffecker and Goldenberg, 1994; Horvath and Partners, 2004; Chow et al., 1997; Epstein and Manzoni, 1997; Kaplan and Norton, $200 \mathrm{la}$, b; Meyer and Markiewicz, 1997; Niven, 20I4).

\section{Conclusions and future research}

To summarize, in a dynamic and changing business environment, implementing management strategies requires integrated performance measurement systems that capture changes in financial and non-financial measures. Performance measurement systems have been developed due to science and experience have concluded that financially-oriented traditional accounting control systems are of limited use for the management of a company. The rising criticism covers aspects such as a disregard of non-financial factors, missing alignment to corporate strategy, a retrospective view, etc. Therefore, several new concepts have been developed.

This paper draws upon the literature about the Balanced Scorecard concept. It is a strategic control system that has the merit of balance between financial and non-financial metrics and between internal and external factors affecting business (innovation) strategy. It links strategic objectives (long-term orientation) with annual budgets (short-term orientation), clarifies and gains consensus about strategic goals, tracks individual and collective performances, and defines and communicates company goals to its internal and external stakeholders.

This paper is limited by several factors that should be addressed in future research. First, this study is grounded in a theoretical secondary data analysis. Reviewing the empirical literature published on the topic of innovation performance measurement and Balanced Scorecard implementation, it has been found out both important evidence for positive effects of utilizing of BSC for innovative performance measurement (e.g. Bigliardi and Bottani, 20I0) and results that 
shed a more critical light on expected benefits stemming from its implementation in Czech SMEs practice. This has to be examined by surveying companies with the help of questionnaires or personal interviews.

Second, it should be noted that the measurement of innovative performance was, is and always will be encumbered by a certain inaccuracy associated with the creative nature of this process. What is detrimental is the fundamental resistance of creative workers to any form of measurement and standardization of their work. However, in view of the importance of the innovative process for the development of the company and the amount of resources put into it, performance measurement in this area is necessary.

Given the high popularity (e.g. Horvath and Partners, 2002; Mooray et al., 1999; Rigby, 2007; Sibbet, 1997) of the Balanced Scorecard on the one hand and serious criticism (e.g. Ittner and Larcker, 200 I; Norreklit, 2003) on the other, it is not surprising that leading researchers have claimed to systematically analyse Balanced Scorecard adoption in companies and its effects (Atkinson et al., 1997; Burkert et al., 2010; Faupel, 2012; Ittner and Larcker, 1998b; Otley, 1999; Wang et al., 2010).

Future research on individual approaches to measuring and managing innovation process performance in Czech SMEs is the objective of post-doc research project of the Czech Science Foundation No. 13-20I23P. It will last till end of 2015 and includes more in-depth research. The substance of this project is to design and verify measures and approach higher credibility of future benefits prediction from innovation processes. Future research is advised to collect, where possible, objective quantitative and also semi-qualitative data on the current state of the investigated issue.

The research focuses on Czech SMEs, since they are key drivers of the Czech economy. They provide around 2 million jobs, generate more than $36 \%$ of the Czech Gross Domestic Product and represent more than $99 \%$ of all Czech enterprises (MIT of the Czech Republic, 20I2).

In-depth research can help understanding the complex interaction between innovation and performance of a company. This becomes even more important in the conditions of the current changing environment and economic situation of Czech SMEs. Well managed and successfully introduced innovation into the market represents a tool for the companies, by means of which they can achieve competitive advantages and enabling their prosperity. Therefore, the effectiveness must be assessed by financial and non-financial criteria in all stages of the innovation process, from the birth of the idea to the final commercialization stage. Research outcomes will help resolve the problem of empirical assess- ment of the importance of individual variables in the determination of future earnings, and will propose measures for the improvement in innovation performance assessment with the use of advanced mathematical methods and models. In this country, such an approach is missing and there is still a big gap in innovation performance measurement.

\section{Acknowledgement}

The author would like to thank Czech Science Foundation for its funding support within postdoc project No. 13-20123P "Innovation Process Performance Assessment: a Management Control System Approach in the Czech Small and Medium-sized Enterprises". 


\section{References}

ANTHONY R.N. (1965) Planning and control systems: Framework for analysis. Boston: Harvard University Press. 180p.

ATKINSON A.A, Balakrishnan R, Booth P, Cote J.M, Groot T, Malmi T, Roberts H, Uliana E and Wu A. (1997) New directions in management accounting research. Journal of Management Accounting Research. 9: 79-108. DOI 10.1016/ SI044-5005(90)7005I-0

AURELI S. (2010) The introduction of innovative performance measurement and management control systems: the role of financial investors and their acquired companies. In Epstein et al. editors. Performance Measurement and management control: Innovative Concepts and practise, Emerald Group Publishing Limited. pp. 8I-I|4. DOI 10.1 I08/s I47935I2(20I0)0000020007

BASSANI C, Lazzarotti V, Manzini R, Pellegrini L, Santomauro $S(2010)$ Measuring performance in R\&NPD: the case of Whitehead Alenia Sistemi Subacquei - a Finmeccanica company. European Journal of Innovation Management. 13(4): 48I-506. DOI I0.1I08/I460I06I0II086302

BESSIRE D and Baker C.R (2005) The French tableau de bord and the American balanced scorecard: A critical analysis. Critical Perspectives on Accounting. 16(6): 645-664. DOI 10.1016/j.cpa.2004.01.004

BIGLIARDI B, and Bottani E (20I0) Implementing the balanced scorecard in the mechanical industry: Evidence from a case study. International Journal of Management and Decision Making. I I (2): I40-I62. DOI I0. I504/ijmdm.20I0.0352 I4

BITICI U.S, Carrie A.S and McDevitt, L (1997) Integrated performance measurement systems: A development guide. International Journal of Operations and Production Management. I7(5): 522-534. DOI I0.I I08/095447897I0I59443

BOSTON Consulting Group (2006) Measuring innovation 2006 https://www.bcgperspectives.com/content/articles/ cost_efficiency_asset_optimization_growth_measuring_innovation_2006 [Accessed 7 July, 20I3]

BOURGUIGNON A, MalleretV and Norreklit H (2004) The American balanced scorecard versus the French tableau de bord: The ideological dimension. Management Accounting Research. 15(2): I07-I34.DOI 10.1016/j.mar.2003.12.006
BREMSER W.G and Barsky N.P (2004) Utilizing the balanced scorecard for R\&D performance measurement. R\&D Management. 34(3): 229-238. DOI I0.IIII/j.I467$9310.2004 .00335 . x$

BURKERT M, Davila A and Oyon, D (2010) Performance consequences of balanced scorecard adoptions: Claim for large-scale evidence and propositions for future research. In Epstein et al. editors. Performance Measurement and management control: Innovative Concepts and practise, Emerald Group Publishing Limited. pp. 345-36I. DOI 10.1 I08/s I 47935I2(2010)00000200I5

COBBOLD I.C and Lawrie G.J.G (2002) Classification of balanced scorecard based on their effectiveness as strategic control or management control tools. Third International Conference on Performance Measurement and Management (PMA 2002). Boston. Pp. I-I0.

CHAKRAVARTHY B.S (1986) Measuring strategic performance. Strategic Management Journal. 7(5): 437-458. DOI 10.1002/smj.4250070505

CHARNES A, Cooper W.W and Rhodes, E (1978) Measuring the efficiency of decision making units. European Journal of Operational Research.2: 429-444. DOI 10.1016/0377$2217(79) 90229-7$

CHIESAV and Frattini F (2009) Evaluation and performance measurement of research and development. Cheltenham: Edward Elgar Publishing. 30 I p. DOI I0.4337/978|84980I942

CHOW C.W, Haddad K.M andWilliamson, J.E (1997).Applying the balanced scorecard to small companies. Management Accounting. 79(2): 21-27.

DAVILA T, Epstein M.J and Shelton R.D (2013) Making innovation work: How to manage it, measure it, and profit from it. Updated ed. Upper Saddle River: FT Press. 348p.

DE GEUSER F, Mooraj S and Oyon, D (2009) Does the balanced scorecard add value? Empirical evidence on its effect on performance. European Accounting Review. 18(1): 93I I 2. DOI I0.1080/09638|8080248|698

EPSTEIN M.J and Manzoni J.F (1997). The balanced scorecard and tableau de bord: Translating strategy into action. Management Accounting: Official Magazine of Institute of Management Accountants. 79(2): 28-36.

EUROPEAN Foundation for Quality Management (1999) EFQM Model for Business Excellence: Company Guidelines. Brussels: EFQM. 
FAUPEL C. (2012) Value-based performance management. Advances in Management Accounting. 20: 187-208. DOI I0.II08/s I 474-787I (20I2)00000200I4

FIORENTINO R (2010) Performance measurement in strategic changes. In Epstein et al editors. Performance Measurement and management control: Innovative Concepts and practise, Emerald Group Publishing Limited. pp. 253-283. DOI I0.II08/s I479-35I2(20I0)00000200I2

GLEICH R (200I) Das System des Performance Measurement: Theoretisches Grundkonzept, Entwicklungs und Anwendungsstand. München:Vahlen. 464p.

HAYES R.H and Abernathy W (1980) Managing our way to economic decline. Harvard Business Review. 58(4): 67-77.

HOFFECKER J and Goldenberg C (1994) Using the balanced scorecard to develop company wide performance measures. Journal of Cost Management. 8(3): 5- 17.

HORVATH and Partners (2004) Nova koncepce controlling. Praha: Profess Consulting. 288p.

HORVATH and Partners. (2002) Balanced Scorecard v praxi. Praha: Profess Consulting. 386p.

HRONEC S.M (1993) Vital signs: using quality, time, and cost performance measurements to chart your company's future. New York:Amacom. 256p.

ITTNER C.D and Larcker, D.F (1998a) Are non financial measures leading indicators of financial performance? An analysis of customer satisfaction. Journal of Accounting Research. 3(3): I-35. DOI 10.2307/249|304

ITTNER C.D and Larcker, D.F (1998b) Innovations in performance measurement: Trends and research implications. Journal of Management Accounting Research. 10: 205-238.

ITTNER C.D and Larcker, D.F (200I) Assessing empirical research in managerial accounting:A value-based management perspective. Journal of Accounting and Economics. 32(I-3): 349-4I0. DOI 10.1016/s0165-4I0I(0I)00026-x

JOHNSON H.T and Kaplan R.S (1987) Relevance lost - The rise and fall of management accounting. Boston: Harvard Business School Press. 296p.

KAPLAN R.S and Norton P.D (1992) The balanced scorecard: Measures that drive performance. Harvard Business Review. 70(I): 7I-79.
KAPLAN R.S and Norton P.D. (1993) Putting the balanced scorecard to work. Harvard Business Review. 7I(5): 134147. DOI 10.1016/b978-0-7506-7009-8.50023-9

KAPLAN R.S and Norton P.D. (1996) The balanced scorecard: Translating strategy into action. Boston: Harvard Business School Press. 336p. DOI 10.1016/s0024-630I(97)80925-9

KAPLAN R.S and Norton P.D (200 la) The strategy focused organization. Boston: Harvard Business School Press. 416p.

KAPLAN R.S and Norton, P.D (200 lb) Transforming the balanced scorecard from performance measurement to strategic management: Part I. Accounting Horizons. I5(2): 87- 104. DOI 10.2308/acch.200I.I5.I.87

KEEGAN D.P, Eiler R.G and Jones C.R (1989) Are your performance measures obsolete? Management Accounting. $70(12): 45-50$.

KERSSENS-VAN Drongelen I.C, Bilderbeek J (1999) R\&D performance measurement: more than choosing a set of metrics. R\&D Management. 29(I):35-46. DOI I0. I I I/I4679310.00115

KERSSENS-VAN Drongelen I.C, Nixon B and Pearson A (2000) Performance measurement in industrial R\&D. International Journal of Management Reviews. 2(2): I I I-I 43. DOI |0. I I | I/|468-2370.00034

KISLINGEROVA E (2008) Inovace nastroju ekonomiky a management organizaci. Praha: C.H.Beck. 315p.

LEBAS M.(1994) Managerial accounting in France-Overview of past traditional and current practise. European Accounting Review. 3(3): 47|-487. DOI I0.1080/09638|89400000032

MCNAIR C, Lynch R.R and Cross K.L (1990) Do financial and nonfinancial measures have to agree? Management Accounting. 5: 26-36.

MERCHANT K (1985) Control in business organizations. Boston: Harvard Business School Press. 16I p.

MERSCHMANN U, Thonemann U.W (20II) Supply chain flexibility, uncertainty and firm performance: an empirical analysis of German manufacturing firms. International Journal of Production Economics. I30(I): 43-53. DOI 10.2139/ ssrn. 1567612

MEYER C (1994) How the right measures help teams excel. Harvard Business Review. 7(3): 95-103. DOI 10.1016/s07376782(95)90039-x 
MEYER D.W and Markiewicz M.A (1997) Developing a balanced scorecard at Wachovia corporation. Bank Accounting and Finances. II (I): I3-20.

MINISTRY of Industry and Trade of the Czech Republic. (20I2). Nova koncepce podpory malych a strednich podnikatelu na obdobi let 2014 az 2020, aneb 52 opatrení pro male a stredni podnikatele. http://www.mpo.cz/dokument l 02987.html [Accessed I July 2013].

MOORAJ S, Oyon D and Hostettler D (1999) The balanced scorecard: A necessary good or an unnecessary evil? European Management Journal. 17(5): 48I-49I. DOI 10.1016/ s0263-2373(99)00034-I

NANNI A.J, Dixon J.R and Vollman T.E (1992) Integrating performance measurement: Management accounting to support new manufacturing realities. Journal of Management Accounting Research. 4: I- I9.

NEELY A (2005) The evolution of performance measurement research. Development in the last decade and a research agenda for the next. International Journal of Operations \& Production Management. 25(I2): I264-1277. DOI 10.1108/01443570510633648

NEELY A and Adams C (200I) The performance prism perspective. Journal of Cost Management. I5(I): 7-I5.

NEUMANN B, Roberts M.K and Cauvin E (2008) Financial and nonfinancial performance measures. Journal of Cost Management. 22(6): 5-I4.

NEUFELD G.A, Semeoni P.A and Taylor M.A (200I) High performance research organizations. Research Technology Management. 44(6): 42-52.

NIVEN P.R (2005) Balanced scorecard diagnostic. Hoboken: John Wiley \& Sons. 224p.

NIVEN P.R (2006) Balanced scorecard step-by-step: Maximizing performance and maintaining results. Hoboken: John Wiley \& Sons. 318p.

NIVEN P.R (20I4) Balanced Scorecard Evolution:A Dynamic Approach to Strategy Execution. Hoboken: John Wiley \& Sons. 368p. DOI 10.1002/978I I I89I50I I

NORREKLIt $\mathrm{H}$ (2003) The balanced scorecard? What is the core? A rhetorical analysis of the balanced scorecard. Accounting, Organizations and Society. 28(6): 597-619. DOI 10.1016/s0361-3682(02)00097-I
OTLEY D (1999) Performance management: A framework for management control systems research. Management Accounting Research. 10(4): 363-382. DOI 10.1006/ mare.1999.0115

PALMER R.J (I992) Strategic goals and objectives and the design of strategic management accounting systems.Advances in Management Accounting. I: 179-204.

PITRA Z. (2006) Management inovacnich aktivit. Praha: Profesional Publishing. 438p.

PRITCHARD R. D, Harrell M.M, DiazGranados D and Guzman M.J (2008) The productivity measurement and enhancement system:A meta-analysis. Journal of Applied Psychology. 93(3): 540-567. DOI I0.1037/002I-90I0.93.3.540

RAAKE A (2008) Strategisches Performace Measurement, Anwendungsstand und Gestaltungsmöglichkeiten am Beispiel des Öffentlichen Personennahverkehrs. Berlin: Lit Verlag. 192p.

RIGBY D (2007) Executive guide - Management tools 2007. Boston: Bain \& Company Publishing. 74p.

SIBBET D (1997) 75 years of management ideas practices 1922-1997. Harvard Business Review. 75(5): 2-I2.

SERFLING K and Schulzte R (1997) Target Costing: Kundenorientierung in Kostenmanagement und Preiskalkulation. In Männel W editor. Frühzeitiges Kostenmanagement. Wiesbaden: Springer. pp. 55-76. DOI 10.1007/978-3-322-845023_4

VAIVIO J (1999) Exploring a "non-financial" management accounting change. Management Accounting Research. 10(4): 409-437. DOI 10.1006/mare.1999.01 I2

WANG J, Lin W and Huang Y.H (2010) A performanceoriented risk management framework for innovative R\&D project. Technovation. 30(II-I2): 60I-6II. DOI I0.10I6/j. technovation.2010.07.003

WESTLUND A.H (200I) Measuring environmental impact on society in the EFQM system. Total Quality Management. I2(I): I25-I35. DOI I0.1080/09544|200200I0|47

ZIZLAVSKY O and Smakalova P (201 I) Research Results in the Field of Information Support for Innovation Activities. Acta Universitatis Agriculturae et Silviculturae Mendelianae Brunensis. 19(4): 387-398. DOI I0.I I I I 